\title{
Kolik peněz z veřejných rozpočtů jde vlastně na sport?
}

\section{How much money from public resources goes really into sports?}

\author{
Marek Pavlík \\ Ekonomicko-správní fakulta, Masarykovy univerzity v Brně
}

\begin{abstract}
Abstrakt:
Podpora sportu z veřejných zdrojů má v České republice tradici a má i svoje ekonomické opodstatnění. $V$ současné době probihá řada diskuzi spojených s problematikou financování sportu, at' už čistě z veřejných zdrojü, tak i např́klad z výnosů loterii. Objevuje se argument, že sport je v současné době v ČR podfinancovaný, a stávající systém financování by mél být změněn. K tomu ovšem potřebujeme védèt, kolik financí do sportu směruje. Naše analýza ukazuje, že tento triviální požadavek není splněn a dostupné informace se významně odlišují. Cílem článku je zjistit, jaký je pravděpodobný objem veřejných prostředků směrovaných do sportu a diskutovat př́činy odlišností v jednotlivých informačních zdrojich. Použitou metodou je komparace dat vládních dokumentů, dat českého statistického úr̆adu a nezávislých studií.
\end{abstract}

\begin{abstract}
:
Granting of sport from public resources has a long tradition in the Czech Republic as well as there are economic reasons for such financial support. The debate about problems of the system sport financing from public budgets is one of up-to-date subjects. Repeatedly is concluded that the Czech sport is under-financed hence current system should be changed. The system can be evaluated only if we know inputs (allocated resources) and output respectively outcomes of the sport policy. The condition of cognition of inputs seems to be trivial; however there are significant differences among available information resources including government documents as well as datasheet from the Czech statistical office and other data sources. Only if we are able to identify inputs we can suggest changes of the whole system of sport financing.

The aim of the paper is to confront information sources about amount of public resources, estimate real value and discuss reasons which caused dissimilarities among information sources.
\end{abstract}

Klíčová slova: Sport, dotace, veřejné zdroje, veřejné finance

Keywords: Sport, grants, public finance, public resources

\section{ÚVOD}

Podpora sportu z veřejných zdrojů má řadu ekonomických i neekonomických důvodů, a stejně tak je v ČR považovaná za určitou tradici. Také Evropská unie konstatuje, že: "grassroots sport, equal opportunities and open access to sporting activities can only be guaranteed through strong public involvement" (Commission of the European Union; pp. 13, 2007).

Systém financování sportu je možné hodnotit a př́ípadně měnit pokud známe množství zdrojů, které do sportu plynou, a víme, jaké výstupy a cíle sledujeme. Právě první podmínka, znalost objemu financí, se jeví jako triviální, avšak existující nejasnosti mezi vládními dokumenty, daty Českého statistického úřadu a dalšími zdroji vedou $\mathrm{k}$ nutnosti zaměřit výzkum právě na tuto oblast před tím, než bude možné navrhovat změny v systému podpory sportu jako takovém.

Běžný ekonomický nebo spíše racionální požadavek maximalizace užitku v tomto případě znamená, aby dané množství vynaložených zdrojů (na sport) přineslo co největší, předem vymezený užitek - tedy aby nedocházelo k plýtvání či zneužívání (Malý, Nemec 2012). Předtím, než půjde analyzovat možnou efektivnost celého systému poskytování dotací, je zřejmě nutné zjistit, o jak velký objem zdrojů jde, z jakých rozpočtů tyto zdroje pocházejí a komu jsou směřovány.

Vláda ve své Koncepci státní podpory sportu v České republice (2011) uvádí, že: „, Finance v českém sportu dosáhly v současné době na historické minimum za poslednich dvacet let. Tento fakt byl částečně kompenzován 
skutečností, že po roce 1990 se výrazně snižila porodnost a počet sportovců z řad talentované mládeže poklesl $v$ rádech desítek procent. Počinaje rokem 2002 se tento trend obrátil a již od roku 2009 můžeme očekávat výrazný nárůst sportujicí mládeže, a to o $28 \%$ do roku 2014. Vzhledem ke stavu veřejných financí je zrejemé, že financování sportu je třeba zajistit i z jiných zdrojü “

Cílem studie je zjistit, jaký je přibližně objem veřejných prostředků, které jsou směřovány do sportu. $\mathrm{S}$ ohledem na to, že množství informačních zdrojů je omezené a současně se informace mezi nimi rozcházejí, jsou diskutovány možné příčiny těchto netriviálních rozdílů.

Pro provedení analýzy byly stanoveny dvě základní výzkumné otázky:

- Jaký je objem veřejných zdrojů směřujících do sportu?

- Jaké mohou být př́íciny významných rozdílů mezi statistickými zdroji?

Není možné předpokládat, že analýza přinese jednoznačné odpovědi na výzkumné otázky, nicméně konfrontace zdrojů mezi sebou by mohla pomoci identifikovat, ty, které lze považovat za přesnější.

\section{METODIKA}

Analýza bude provedena na základě sekundární analýzy dat publikovaných v následujících informačních zdrojích:

- Analýza financování sportu v ČR (2009) - Materiál vypracovaný ve spolupráci Ministerstva školství, mládeže a tělovýchovy a Českého olympijského výboru.

- Statistická ročenka ČR (2011) - publikováno Českým statistickým úřadem.

- Koncepce financování sportu v České republice. Analyticko-koncepční studie KPMG (2012) - dokument zpracovaný firmou KPGM ve spolupráci s Českým olympijským výborem.

- Rozbor financování NNO z veřejných rozpočtů v roce 2010 - dokument publikovaný vládou ČR a schválený usnesením č.5 ze 4.1.2012.

- Data dostupná na Ministerstvu školství pro rok 2010 - rozdělení dotací.

Zjištěné údaje budou konfrontovány a provedena diskuze možných příčin v odlišnosti výsledků. Aby bylo možné komparovat některé zdroje, bude vždy pracováno s předpokladem, že Česká republika má 10 mil. obyvatel a směnný kurz je $25 \mathrm{Kč} \mathrm{za} 1 €$. Pro Slovenskou republiku je potom pracováno s počtem obyvatel 5,4 mil. a směnným kurzem 30 SK za $1 €$.

S ohledem na dostupnost jednotlivých dat nebude možné konfrontovat mezi sebou stejné roky, jako referenční rámec bylo zvoleno období 2008-2010 s tím, že dostupné zdroje (ČSÚ, KPMG) s delšími časovými řadami nevykazují významnější změny trendů mezi jednotlivými roky. Bude tedy pracováno s předpokladem, že rámcovou představu splňuje i srovnání v rámci referenčního období.

\section{VÝSLEDKY}

\section{Analýza financování sportu 2009 (Výzkumná zpráva MŠMT)}

Prvním zdrojem informací je „Analýza financování sportu 2009“, což dokument veřejně dostupný na internetových stránkách MŠMT. Tento dokument současně sloužil jako jeden z materiálů pro konferenci „Sport a stát“ konanou v roce 2010 pod záštitou předsedy vlády J. Fišera. Výsledky obsažené v této zprávě tvořily poměrně silný argument pro diskuzi o př́padné podfinancovanosti sportu v České republice. Na tuto analýzu navazuje potom „Koncepce státní podpory sportu v České republice“ - dokument schválený Vládou ČR usnesením číslo 167 ze dne 9. března 2011.

Následující dva obrázky prezentují hlavní zjištění o pozici ČRve srovnání s dalšími evropskými zeměmi. V př́ípadě obrázku 1 jsou srovnávány dva informační zdroje:

- $\quad$ První sloupec zleva označuje kalkulaci opírající se o studii zpracovanou během Francouzského předsednictví EU.

Druhý sloupec vychází z kalkulace opírající se o údaje Bílé knihy o sportu a Ekonomického fóra v Davosu. 
Kalkulace ${ }^{1}$ celkového př́nosu sportu vychází z předpokladu, že průměrný Evropan utratí za sportovní služby a zboží 177 euro za rok, což (při přepočtu na počet obyvatel, směnný kurz a sazbu DPH) vede k hodnotě 8,8 mld. Kč. Obdobně byl stanoven př́nos sportu ve druhém př́ípadě, kdy je z HDP ČR odvozena hodnota $3,7 \%{ }^{2}$,která dle evropských studií připadá na sport.

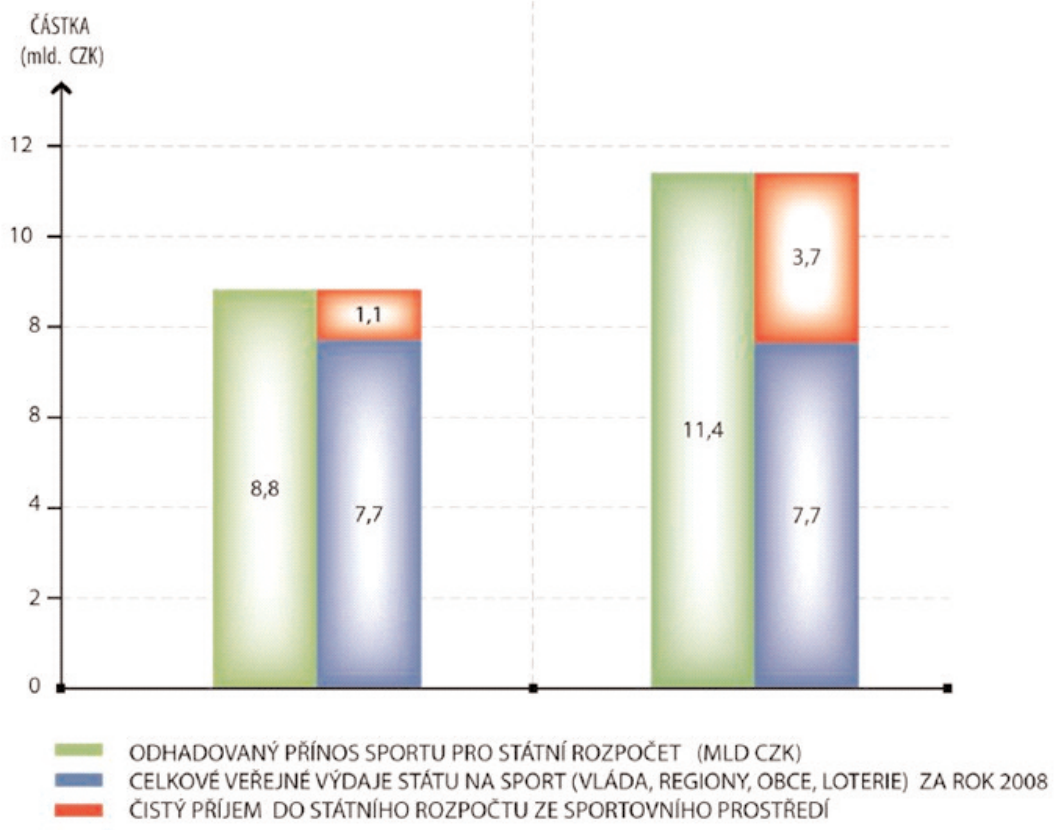

Obr. 1. Analýza financování sportu 2009 - přinos sportu

Zdroj: Analýza financování sportu (2009)

Obrázek 2 potom prezentuje přepočet výdajů na jednoho obyvatele v eurech ve srovnání s ostatními evropskými zeměmi. Česká republika se umist'uje na velmi nelichotivé pozici. V metodologické části autoři připouštění aproximaci některých dat, která shromažd’ovali na základě dotazníků.

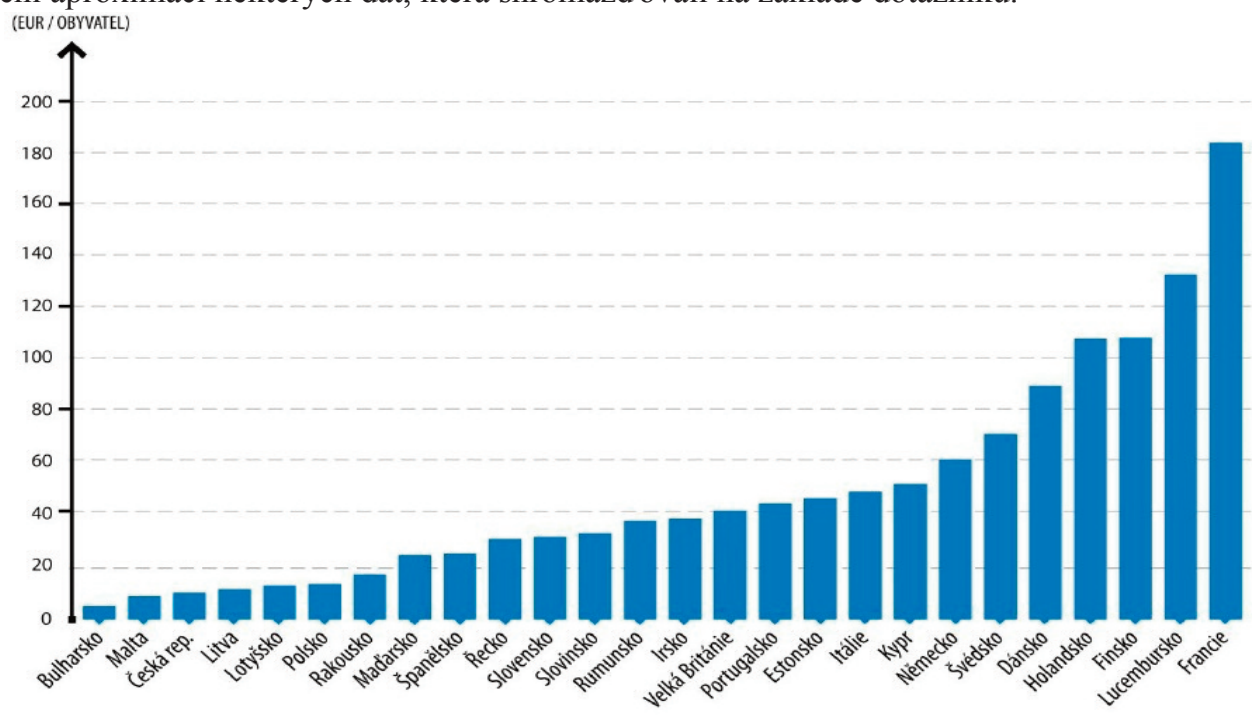

Obr. 2. Země EU - porovnání veřejných výdajů na sport na obyvatele v eurech

Zdroj: Analýza financování sportu v ČR (2009)

\footnotetext{
1 Zpracováno podle: Analýza financování sportu (2009)

2 Novotný (2011) odhaduje velikost sportovního trhu v ČR 2 \% HDP Zjištění
} 
Z obrázku 2 vyplývá, že na 1 obyvatele připadá výdaj přibližně ve výši 10 euro. Po přepočtu jde o sumu 2,5 mld. Kč. Z obrázku 1 vyplývá, že přínosy sportu pro státní rozpočet jsou kalkulovány ve výši 7,7 mld. Kč. Pokud bychom do grafu na obrázku 2 chtěli zapracovat hodnotu 7,7 mld. Kč uvedenou v téže výzkumné zprávě, potom se ČR dostane na hodnotu 30,8 euro na obyvatele (ceteris paribus).

Tyto dva zdroje v jedné zprávě se tedy rozchází o 5,2 mld. Kč, nabízí se však vysvětlení, že v príípadě obrázku 2 se možná jedná (zpráva to nijak neuvádí) pouze o výdaje ze státního rozpočtu a nikoliv výdaje z veřejných rozpočtů celkem. Pro srovnání Slovensko zde má uvedenou hodnotu přibližně 36 euro. Pro rok 2008 byly identifikovány tyto výdaje ze státního rozpočtu Slovenské republiky. Po přepočtu jde výdaj ve výši 14,3 eur na jednoho obyvatele.

Tab. 1. Výdaje na sport ze státního rozpočtu Slovenské republiky

Zdroj: Výsledky hospodárenia štátneho rozpočtu Slovenskej republiky v roku 2008

\begin{tabular}{|l|r|}
\hline Typ výdaje & V tis. SK \\
\hline Výdaje státního rozpočtu na rekreaci a sport & 1094408 \\
\hline Programové financování - program rozvoje sportu v SR & 1085717 \\
\hline Sportovní gymnázia & 145645 \\
\hline
\end{tabular}

\section{Český statistický úřad}

Dalším zdrojem dat jsou statistiky Českého statistického úřadu, dostupné ve statistických ročenkách ČR. Výsledky za rok 2008 a 2010 jsou obsaženy v tabulce 2 především pro potvrzení trendového vývoje.

Tab. 2. Výdaje na tělovýchovu v letech 2007 - 2011 v mil. Kč

\begin{tabular}{|r|r|r|r|r|r|}
\hline & \multicolumn{2}{|c|}{ Státní rozpočet } & \multicolumn{2}{c|}{ Územní rozpočty } & \multirow{2}{*}{} \\
\cline { 2 - 5 } & Běžné výdaje & $\begin{array}{c}\text { Kapitálové } \\
\text { výdaje }\end{array}$ & $\begin{array}{c}\text { Běžné } \\
\text { výdaje }\end{array}$ & $\begin{array}{c}\text { Kapitálové } \\
\text { výdaje }\end{array}$ & Celkem \\
\hline 2007 & 1523 & 698 & 3864 & 4786 & 10871 \\
\hline 2008 & 1854 & 1260 & 4246 & 4724 & 12084 \\
\hline 2009 & 1440 & 737 & 4552 & 5847 & 12576 \\
\hline 2010 & 1736 & 651 & 4474 & 6255 & 13116 \\
\hline 2011 & 1807 & 837 & 4563 & 3608 & 10815 \\
\hline
\end{tabular}

Zdroj: ČSÚ Výdaje státního rozpočtu a územnich rozpočtů na kulturu a sport

Po přepočtu (ceteris paribus) 12,08 mld. Kč v roce 2008 docházíme k výdajům na obyvatele ve výši 48 euro. Rok 2010 znamená celkově 13,1mld. Kč a výdaj na obyvatele ve výši 52 euro.

\section{Koncepce financování sportu v ČR (nevládní studie)}

Následující Koncepce financování sportu v ČR byla zpracována firmou KMPG ve spolupráci s Českým olympijským výborem na základě dat z Ministerstva financí. Pro rok 2008 (2010) zde dochází k celkové sumě 16,6 mld. Kč (resp. 17,8 mld. Kč), což při přepočtu vychází na 66 euro na obyvatele (resp. 71,4 euro na obyvatele). 
Tab. 3. Finanční zdroje z veřejných rozpočtů v letech 2007-2011

Zdroj: KPMG (2012) Koncepce financováni sportu v České republice. Analyticko-koncepčni studie

Poznámka: DSO - Dobrovolné svazky obcí

\begin{tabular}{|c|c|c|c|c|c|c|}
\hline Rok & MŠMT & $\begin{array}{l}\text { Ostatní } \\
\text { ministerstva }\end{array}$ & Obce a DSO & Krajské úřady & Regionální rady & $\begin{array}{l}\text { Celkem za } \\
\text { subjekty }\end{array}$ \\
\hline 2007 & 3302 & 1501 & 10364 & 1133 & 0 & 16299 \\
\hline 2008 & 2605 & 1728 & 11000 & 1271 & 20 & 16624 \\
\hline 2009 & 2113 & 1353 & 12857 & 1291 & 409 & 18023 \\
\hline 2010 & 2059 & 670 & 13508 & 1209 & 407 & 17853 \\
\hline 2011 & 2286 & 699 & 9976 & 1351 & 356 & 14666 \\
\hline $\begin{array}{l}\text { Průměry za } \\
\text { subjekt }\end{array}$ & 2473 & 1190 & 11541 & 1251 & 238 & 16693 \\
\hline
\end{tabular}

\section{Rozbor financování NNO z veřejných rozpočtů v roce 2010}

Rozbor financování nestátních neziskových organizací představuje pouze doplňkový zdroj informací, nebot' př́íjemci dotací mohou být i jiné než nestátní neziskové organizace (například příspěvkové organizace, organizační složky státu, př́padně i obchodní společnosti). Předpokládáme, že většinu zdrojů z veřejných dotací dostávají NNO.

V roce 2010 tento zdroj uvádí, že bylo alokováno 1908042 tis. Kč na tělovýchovu (z toho 717552 tis. Kč na reprezentaci). Pokud tuto informaci konfrontujeme s údaji MŠMT pro rok 2010, docházíme k sumě nižší o 329482 tis. Kč (dotace pro rezortní sportovní centra nelze považovat za dotace NNO - jde o organizační složku státu). Pokud by do této sumy měly být započítány dotace na organizační složky státu, pak by zřejmě chyběly výdaje na RSC v gesci Ministerstva vnitra a Ministerstva obrany.

Oproti očekávání je suma uváděná na MŠMT nižší, než jak vyplývá z Rozboru financování NNO, kde je jako zdroj uvedena databáze kapitol státního rozpočtu

Tab. 4. Výdaje z rozpočtu kapitoly MŠMT v roce 2010

Zdroj: MŠMT (1) a MŠMT (2)

\begin{tabular}{|l|r|}
\hline Účel & částka v tis. Kč \\
\hline Veřejně prospěšné programy & 311624 \\
\hline ostatní dotace & 922 \\
\hline Program obnovy MTZ 23350 - sport. organizace & 432769 \\
\hline Program obnovy MTZ 23350 - reprezentace & 144132 \\
\hline Dotace pro státní reprezentaci & 625234 \\
\hline Rezortní sportovní centra & 361193 \\
\hline Dotace pro sportovní gymnázia & 63879 \\
\hline Celkem & 1939753 \\
\hline
\end{tabular}

\section{Starší prameny}

Určitou, byt’ neaktuální představu o objemu veřejných zdrojů podává ještě pramen Hobza, Dohnal, Cikl (2008) ve stati Koordinace dotační politiky jako faktor efektivnosti řízení veřejného sektoru. Údaje končí rokem 2006, nicméně bylo by možné uvažovat o určitém trendovém vývoji. 


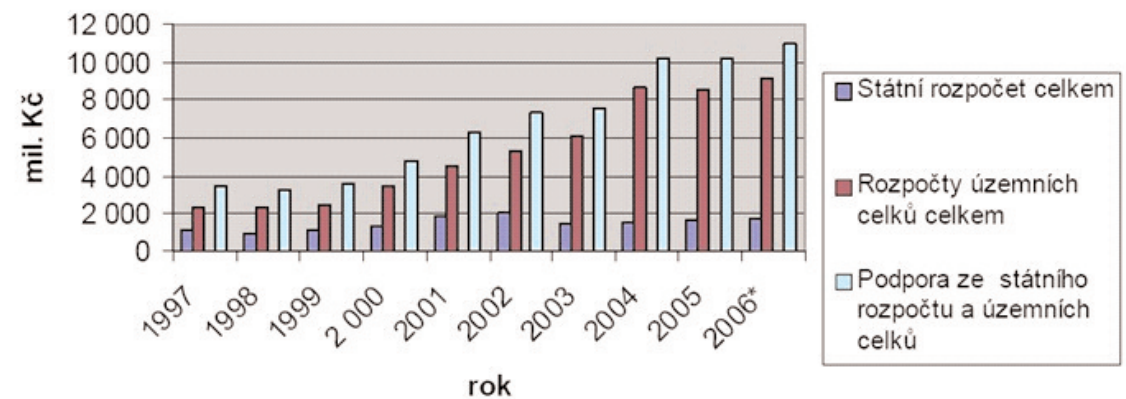

Obr. 3. Podpora sportu a tělovýchovy z veřejných rozpočtů

Zdroj: Hobza, Dohnal, Cikl (2008)

Novotný (2011) potom prezentuje výdaje ze státního rozpočtu v objemu cca 2,6 mld. Kč pro rok 2007 a 1,9 mld. Kč pro rok 2009, kde využívá informace z odboru sportu MŠMT.

\section{DISKUSE}

V úvodu byly nastoleny dvě výzkumné otázky:

- Jaký je objem veřejných zdrojů směrujících do sportu?

- Jaké mohou být příčiny významných rozdílů mezi statistickými zdroji?

Pro zodpovězení první otázky lze použít srovnání výsledků v tabulce 5 , kde byly identifikovány tyto možné výsledky:

Tab. 5. Komparace zdrojů dat o objemu veřejných prostředki̊ alokovaných na sport

Poznámka: *) rok 2008 nebyl u grafu uveden, v kontextu ostatnich dat je tento rok předpokládán

Zdroj: sestaveno autorem

\begin{tabular}{|l|r|r|r|r|r|}
\hline \multicolumn{1}{|c|}{ pramen } & rok & $\begin{array}{c}\text { Celkový objem } \\
\text { zdrojů v mil. Kč }\end{array}$ & $\begin{array}{c}\text { v EUR na 1 } \\
\text { obyvatele }\end{array}$ & $\begin{array}{c}\text { státní } \\
\text { rozpočet }\end{array}$ & Municipality \\
\hline Novotný, Dohnal, Cikl & 2006 & 11000 & 44 & 1900 & 9100 \\
\hline Analýza financování sportu-graf2.1.5 & 2008 & 7700 & 31 & NA & NA \\
\hline Analýza financování sportu - graf 4.1.3 & $2008 *$ & 2500 & 10 & NA & NA \\
\hline Český statistický úrad & 2008 & 12084 & 48 & 3114 & 8970 \\
\hline Český statistický úr̆ad & 2010 & 13116 & 52 & 2387 & 10729 \\
\hline Koncepce financování sportu - KPMG & 2008 & 16624 & 66 & 4333 & 12291 \\
\hline Koncepce financování sportu - KPMG & 2010 & 17853 & 71 & 2729 & 15124 \\
\hline
\end{tabular}

V rozporu s daty ČSÚ a daty studie KPMG potom není informace z Rozboru financování nestátních neziskových organizací z veřejných rozpočtů, Novotný (2011) a stejně tak vlastní šetření, kdy v obou př́padech je identifikována suma výdajů ze státního rozpočtu větší než 1,9 mld. Kč při abstrahování od výdajủ alokovaných na organizační složky státu a výdajů ze zdrojů Ministerstva obrany a Ministerstva vnitra.

Vyloučením extrémů a porovnáním s dostupnými daty rozpočtu MŠMT lze uvažovat o tom, že roční objem dotací ze státního rozpočtu (pro období 2008-2010) kolísá zhruba mezi 1,9-2,5 mld. Kč, přičemž objem zdrojů z municipalit se pohybuje mezi 8-9 mld. Kč. Poměrné značné rozpětí takových odhadů není rozhodně uspokojivé. Představu o rozptylu ilustruje obrázek 5 o pozici ČR ve srovnání s ostatními zeměmi a alternativními výpočty.

V kontextu korektní interpretace je však nutné připustit, že stejnou chybou, jakou jsou patrně zatížena data za Českou republiku, mohou být zatížena data ostatních srovnávaných zemí. Zásadní jsou v tomto směru důvody, proč k těmto odlišnostem dochází. 


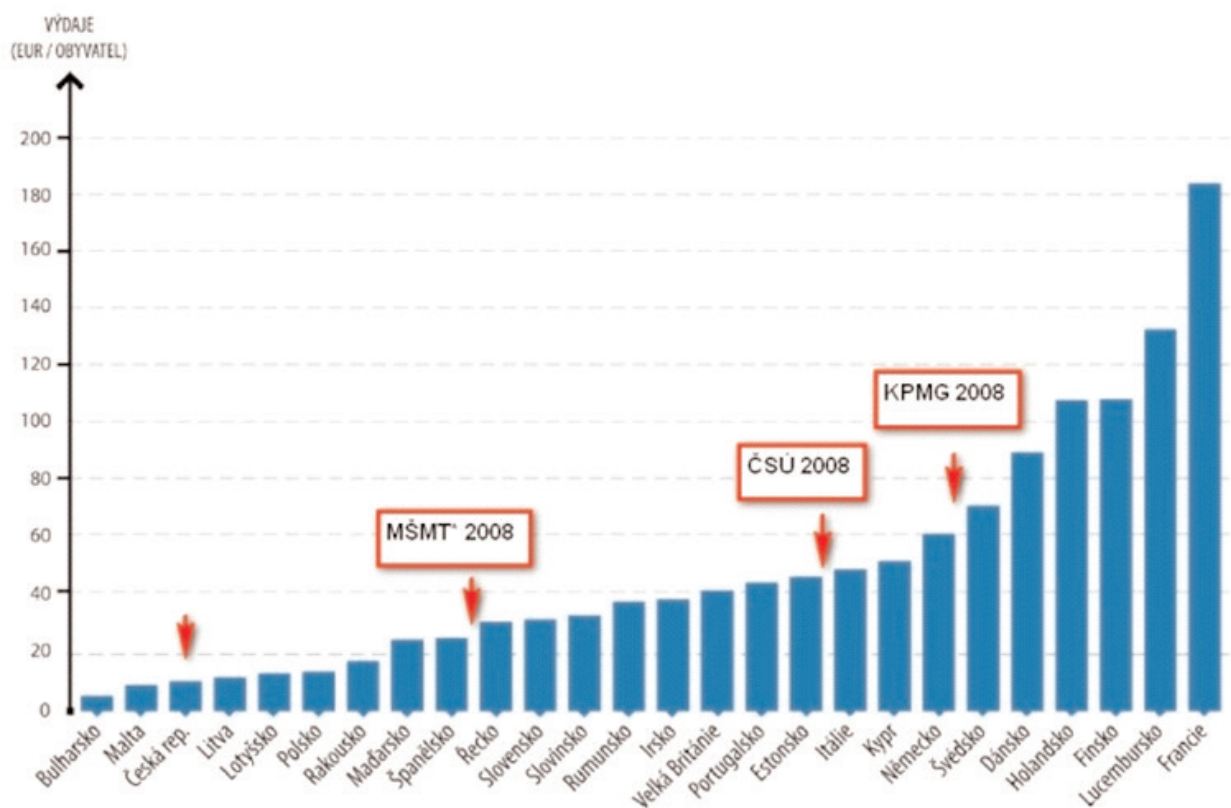

Obr. 4. Množstvi veřejných zdrojü na sport-alternativni výsledky

Poznámka: MŠMT* - Analýza financováni sportu, graf 5.1.2 výsledný efekt pro státní rozpočet

Zdroj: Analýza financováni sportu v $\breve{C} R$ (2009) - upraveno autorem

Proč dochází k těmto rozdílům, nelze jednoznačně odpovědět. Lze identifikovat tyto možné příčiny:

Metodologické odlišnosti. Rozklíčování dotací na sport nemusí být jednoduché zejména na úrovni mu nicipalit, kde se dotace neziskovým organizacím rozdělují často společně v balíku s dotacemi pro kulturu, volnočasové aktivity a aktivity mládeže. Tento typ metodického problému současně přinášejí patrně největší zkreslení na úrovni dat z municipalit. Každý kraj a obec si v rámci své samo statné působnosti stanovuje vlastní politiku pro oblast sportu, proto v některých př́padech stoji politika sportu samostatně, jindy spolu se školstvím či kulturou. Analogicky k tomu potom vznikají dotační tituly, kde dochází k rozdělování dotací pro organizaci do cílů této politiky zahrnuté. Je o problémy jako např́klad:

o Je dotace pro organizaci typu Sokol čistě dotací na sport, pokud organizace provozuje i kulturní aktivity?

o Dotace pro skautskou organizaci může spadat do kategorie sport nebo do volnočasové aktivity mládeže.

Odhad chybějících dat.

Odlišná metodika sběru a analýzy dat v zahraniční.

„Ekonomická data ze sportovní oblasti jsou obtížně dostupná a často ani neexistují ve srovnatelně definovaných ukazatelích, nebot' sport není samostatným statisticky sledovaným oborem. To platí jak pro Českou republiku, tak i pro většinu ostatních států EU.“ (Analýza financování sportu 2009)

Drobné odlišnosti mohou být spojeny s časem sběru dat, nepochybně budou existovat rozdíly mezi rozpočtem schváleným, upraveným či výsledným.

Dohledání a verifikace dat např́klad z rozpočtů ministerstev je značně problematická (typicky vý daje na sport z kapitol MO a MV). Problematické může byt odlišování sportu od formy př́pravy na výkon povolání (policejní a hasičský sport).

Problematické použití termínů sport a tělovýchova, kdy není zcela jednoznačné, jak je nakládáno s dotacemi a investicemi pro školní (rozšířenou) tělesnou výchovu. Například v případě investic by bylo nutné odlišovat, zda výsledky této investice slouží pouze v rámci školní tělesné výchovy, nebo sekundárně přinášejí užitek dalším sportovním klubům (sportovcům).

Možné neodlišování dotací pro neziskové organizace od dotací příspěvkovým organizacím a organizačními složkám státu - v agregovaných součtech.

Logickou možností je potom opomenutí nebo dokonce záměrný omyl při zpracování dat. 


\section{ZÁVĚRY}

Předchozí analýza ukázala poměrně značné rozdíly v uváděném objemu veřejných zdrojů alokovaných na sport. Před diskuzí o podfinancovanosti sportu či nevhodném způsobu rozdělování dotací na sport je tedy nezbytné především určit, jaký objem zdrojů reálně do sportu směřuje. V textu nebyly hodnoceny zdroje, které do sportu směřují z výnosů loterií (at' už původní systém odvodu části výtěžku na veřejně prospěšné účely nebo jeho novelizovaná podoba). Na základě porovnání jednotlivých zdrojů je možné konstatovat, že celkový objem veřejných zdrojů ve zkoumané období překračuje 10 mld.Kč. Na úrovni státního rozpočtu se objem zdrojů pohybuje okolo 2 mld. Kč.Předpokládáme, že objem veřejných zdrojů na sport se pohybuje nad hranicí 12 mld. korun, což při komparaci s dalšími evropskými zeměmi Českou republiku staví lehce nad průměr zemí EU.

Existuje celá řada možných přičin statistických rozdílů mezi zdroji dat, jejich diskuze a řešení jsou nezbytným krokem ke zvýšení transparentnosti celého systému. Identifikovali jsme klíčové metodologické problémy a to: odlišování sportovních aktivit od kulturních a volnočasových; podchycení investičních aktivit pro sport a to zejména tam, kde je sport jednou z několika oblastí zájmu celkové investice.

Z ekonomického hlediska je zásadní hledat cestu, jak s daným množstvím peněz vytvořit co největší užitek pro sport a sportovce. Není možné současně opomenout, že debata o vhodném systému financování bude vždy ovlivněna normativním pohledem na priority v podobě sportovních výstupů, tedy např́klad jak stát resp. společnost považuje za hodnotné úspěchy reprezentantů, nebo stejně tak, jak hodnotné jsou cíle v podobě popularizace amatérského sportu.

\section{LITERATURA}

Analýza financování sportu v ČR (2009) - [Online 09.2012] http://www.msmt.cz/sport/analyza-financovanisportu-v-ceske-republice

Commission of the European Union (2007a): White paper on sport.Brusel.[online]http://ec.europa.eu/sport/ white-paper/doc/wp_on_sport_en.pdf

Český statistický úřad - Statistická ročenka 2009.[Online09.2012]www.czso. cz/csu/2011edicniplan.nsf/t/ 330 03256BE/\$File/0001112629.xls

Český statistický úřad - Statistická ročenka 2010. [Online 03.2013]www.czso.cz/csu/2010edicniplan.nsf /t/46002D8AC2/\$File/0001102629.xls

Český statistický úřad - Statistická ročenka 2011. [Online 09.2012] www.czso.cz/csu/ 2011edicniplan.nsf/ t/33003256BE/\$File/0001112629.xls

Český statistický úřad - Statistická ročenka 2012. [Online 03.2013]www.czso.cz/csu/ 2012edicniplan.nsf/t/ 9D003B6FFD/\$File/0001122629.xls

Hobza, V., Dohnal, T.,Cikl, R. (2008) Koordinace dotační politiky jako faktor efektivnosti řízení veřejného sektoru studie $\mathrm{k}$ dotaci sportu. In Veřejné politiky a jejich účinnost - determinanty raciálnosti řizení ve veřejném sektoru (sborník přispěvki̊ z mezinárodního vědeckého semináre). 1. vyd. Brno: ESF MU. ISBN 9788073993450 http://www.msmt.cz/sport/rozdeleni-statniho-rozpoctu-2010-v-oblasti-sportu-vydajovy-2

KMPG (2012). Koncepce financování sportu v České republice. Analyticko-koncepční studie (2012) http://www.olympic.cz/public/img/dokumenty/koncepce_financovani_sportu_prezentace_v9a.pdf

Ministerstvo školství, mládeže a tělovýchovy (1) - Rozdělení Státního rozpočtu 2010 v oblasti sportu - výdajový okruh: "Tělovýchova včetně programu 233510" - Investice. [Online 09.2012] http://www.msmt.cz/sport/rozdeleni-statniho-rozpoctu-2010-v-oblasti-sportu-vydajovy-1

Ministerstvo školství, mládeže a tělovýchovy (2) - Rozdělení Státního rozpočtu 2010 v oblasti sportu - výdajový okruh: "Sportovní reprezentace bez programu 233510". [Online 09.2012]

Ministerstvo školství, mládeže a tělovýchovy (3) - Koncepce státní podpory sportu v české republice (2011). [Online 09.2012] http://www.msmt.cz/sport/koncepce-statni-podpory-sportu-v-ceske-republice

Nemec, J., Malý, I.Možnosti zvyšování efektivnosti veřejného sektoru v podmínkách krize veřejných financí. 1. vyd. Brno: Masarykova univerzita, 2012. 222 s. neuveden. ISBN 978-80-210-5668-8. doi:10.5817/CZ.MUNI.M210-5668-2011

Novotný, J.. Sport v ekonomice. Vyd. 1. Praha: WoltersKluwer Česká republika, 2011, 512 s. ISBN 9788073576660. 
Rozbor financování nestátních neziskových organizací z veřejných rozpočtu v roce 2010. [Online 09.2012] http://vlada.cz/assets/ppov/rnno/dokumenty/rozbor_2010.pdf

Slovenský statistický úřad - Výsledky hospodáreniaštátneho rozpočtu Slovenskej republiky v roku 2008. [Online 09.2012] http://www.finance.gov.sk/Components/CategoryDocuments/s_LoadDocument.aspx?categoryId $=7302 \&$ documentId $=3724$ 